\title{
Lupus
}

http://lup.sagepub.com

Soy isoflavones supplementation alleviates disease severity in autoimmune-prone MRL-Ipr/lpr mice

YH Hong, TC Wang, CJ Huang, WY Cheng and BF Lin

Lupus 2008; $17 ; 814$

DOI: $10.1177 / 0961203308091287$

The online version of this article can be found at:

http://lup.sagepub.com/cgi/content/abstract/17/9/814

\author{
Published by: \\ (1)SAGE \\ http://www.sagepublications.com
}

Additional services and information for Lupus can be found at:

Email Alerts: http://lup.sagepub.com/cgi/alerts

Subscriptions: http://lup.sagepub.com/subscriptions

Reprints: http://www.sagepub.com/journalsReprints.nav

Permissions: http://www.sagepub.co.uk/journalsPermissions.nav

Citations http://lup.sagepub.com/cgi/content/refs/17/9/814 


\title{
PAPER
}

\section{Soy isoflavones supplementation alleviates disease severity in autoimmune-prone MRL-lprllpr mice}

\author{
YH Hong ${ }^{1}$, TC Wang ${ }^{1}$, CJ Huang ${ }^{1}$, WY Cheng ${ }^{1,2}$ and BF Lin ${ }^{1}$ \\ ${ }^{1}$ Department of Biochemical Science and Technology, Institute of Microbiology and Biochemistry, College of Life Science, National Taiwan University, \\ Taipei, Taiwan, Republic of China; and ${ }^{2}$ Department of Medical Nutrition, I-Shou University, Kaohsiung County, Taiwan, Republic of China
}

\begin{abstract}
Soy isoflavones supplements, which are phyto-oestrogens widely used as alternatives to alleviate menopausal syndromes or prevent chronic diseases, may exert oestrogenic and anti-oestrogenic activities. This study aimed to investigate the effects of soy isoflavones supplement on oestrogenrelated autoimmune disease, such as systemic lupus erythematosus, using autoimmune-prone female MRL-lpr/lpr mice. Eighty mice of 8 weeks were divided into five groups: 0 (Control), 2 (Isf 2), 10 (Isf 10) and 20 (Isf 20) $\mathrm{mg} / \mathrm{kg} \mathrm{BW/day} \mathrm{Phyto} \mathrm{Soya}{ }^{\mathrm{TM}}$ isoflavones or $0.375 \mathrm{mg} / \mathrm{kg} \mathrm{BW} /$ day tamoxifen (TAM) as the positive control, by tube-feeding. Some mice were killed at age 15 weeks for cellular cytokine secretion. The data suggested that the Isf 20 and TAM groups had higher weight gain and survival compared with the control group. At age 22 weeks, the Isf 20 group still had $75 \%$ survival comparable to mice treated with TAM. At age 14 weeks, the TAM group showed significantly lower serum anti-double-stranded (ds) DNA IgG and anti-cardiolipin IgG The mice in the Isf 10 and Isf 20 groups also had lower anti-dsDNA IgG and anti-cardiolipin IgG. The interferon (IFN)- $\gamma$ secretion from mitogen-stimulated T cells in the Isf 20 and TAM groups were significantly lower than those of control mice. Furthermore, the oestrogenic activity of the methanol extracts of soy isoflavones for oestrogen receptor (ER) $\beta$, but not ER $\alpha$, significantly increased, suggesting that soy isoflavones have a selective modulation of ER activation. Thus, soy isoflavone supplementation did not aggravate murine lupus, but apparently ameliorated the disease. Lupus (2008) 17, 814-821.
\end{abstract}

Key words: autoantibody; IFN- $\gamma$; MRL-lpr/lpr; oestrogen receptor; soy isoflavones

\section{Introduction}

Systemic lupus erythematosus (SLE) is a chronic, inflammatory autoimmune disorder. The autoantibodies production may affect the skin, kidneys, joints, brain and other organs. Women develop SLE nine times more frequently than men, especially during the child-bearing period, and disease flares are associated with certain phases of the menstrual cycle. ${ }^{1-3}$ Accordingly, oestrogen is correlated with SLE progression and even conceived as an accelerator of the disease process. The onset of disease is triggered in lupus patients when they take oestrogen-containing oral contraceptives. ${ }^{4}$ It has also been documented that oestrogen treatment can exacerbate the disease, 5,6 whereas the administration of anti-oestrogen agents retard the disease in lupus-like mice. ${ }^{7}$ Tamoxifen (TAM), a synthetic non-steroidal triphenylethylene compound, is a potent oestrogen antagonist with

Correspondence to: Bi-Fong Lin, PhD, Department of Biochemical Science and Technology, Institute of Microbiology and Biochemistry, College of Life Science, National Taiwan University, No. 1, Roosevelt Road, Section 4, Taipei, Taiwan, Republic of China.

Email: bifong@ntu.edu.tw

Received 30 November 2007; accepted 3 March 2008 high affinity for oestrogen receptor (ER) and has been used as a preventive drug for breast cancer disease. ${ }^{8,9}$ Several studies have shown that TAM alleviates disease severity in experimental lupus mice and lupus-like mice by decreasing $\mathrm{CD} 5^{+} \mathrm{B}$-cell population, soluble tumour necrosis factor (TNF) receptors, renal inflammation and double negative T cells. ${ }^{10-12}$

Lupus-like mice, such as MRL-lpr/lpr mice, spontaneously develop an autoimmune disorder resembling human SLE characterized by the production of various autoantibodies, immune complex-mediated glomerulonephritis, vasculitis, arthritis and massive lymph node proliferation related to the lpr gene encoding a mutant form of Fas. This prompts the progress of fulminant humoral autoimmune disease. ${ }^{13,14}$ Most MRL-lpr/lpr mice develop a progressive loss of kidney function at 3-6 months of age and with a $50 \%$ mortality rate at 6 months of age. These mice are a valuable resource for studying the effects of environmental and dietary exposures on a genetically susceptible population. ${ }^{15}$

Although epidemiological studies suggests that the low incidence of certain oestrogen-related chronic diseases in Asian women is attributable to their high intake of soyfoods, soy isoflavones supplement have 
become widely used as alternatives to alleviate menopausal syndrome or prevent chronic disease. ${ }^{16}$ Soyfoods contain high levels of isoflavones, such as genistein, daidzein and equol, which are structurally similar to $17 \beta$-estradiol (E2) and have oestrogenic effects. The action of oestrogen is mediated by its specific receptor in target cells. The ER, including ER $\alpha$ and ER $\beta$, becomes activated following its binding to oestrogen, which then interacts with the oestrogen responsive element in the promoters of oestrogen responsive target genes and regulates their transcription. ${ }^{17}$

However, adverse effects of oestrogen on SLE raised concern that similar effect of soy isoflavones supplement could also occur in SLE-prone female individuals. On the other hand, soy isoflavone has been shown to possess anti-inflammatory effects and reduce proteinuria and renal pathological lesions associated with progressive renal failure, which are beneficial for SLE. ${ }^{18,19}$ Therefore, whether those soy isoflavone products available in market or health stores could affect autoimmune disease, such as SLE, need to be investigated. In this study, we used MRL-lpr/lpr mice to examine whether soy isoflavones supplement can ameliorate or exacerbate lupus-prone disease symptoms, such as life span, proteinuria, autoantibodies and cytokines levels.

\section{Materials and methods}

\section{Experimental animals and diets}

Eighty 6-week-old female MRL-lpr/lpr mice were purchased from the Animal Center of the College of Medicine at the National Taiwan University (Taipei, Taiwan). The animal room was maintained on a 12-h light-dark cycle with constant temperature $\left(23 \pm 2{ }^{\circ} \mathrm{C}\right)$ and humidity in stainless steel cages with glass water bottles. Mice were fed a non-purified chow diet (Lab Rodent Chow 5001, Ralston Purina, St. Louis, MO, USA) first for adaptation, and then switched to soy-free and oestrogen-free AIN-76 diet, 20 in which corn oil is substituted by sunflower oil (SO). Mice at age 8 weeks were randomly assigned to five groups: control, tamoxifen (TAM), Phyto Soya $^{\mathrm{TM}}$ isoflavones $2 \mathrm{mg} / \mathrm{kg} \mathrm{BW}$ (Isf 2), $10 \mathrm{mg} / \mathrm{kg}$ BW (Isf 10) and $20 \mathrm{mg} / \mathrm{kg} \mathrm{BW}$ (Isf 20), respectively, and each group contained 15-17 mice. TAM with the dose of $0.375 \mathrm{mg} / \mathrm{kg} \mathrm{BW}$ was used as the positive control that referred to the previous study. ${ }^{12}$ Soy isoflavones used in this experiment was Phyto Soya ${ }^{\mathrm{TM}}$ capsule kindly supplied by Arkopharma Ltd (Carros, France) through Morris Enterprise Co. Ltd (Taipei, Taiwan). Phyto Soya ${ }^{\mathrm{TM}}$ contains $4.1 \%$ (w/ w) soy isoflavones extracted from natural soy germ with the following distribution of isoflavone: $50 \%$ daidzin, 30\% glycitin and $20 \%$ genistin.

All mice had free access to food and water, and were additionally tube-fed either $50 \mu \mathrm{l} \mathrm{SO}$ or the above dosage of samples in $50 \mu \mathrm{l}$ SO 5 days every week. Food intake, body weight and the proteinuria were regularly monitored. At age 15 weeks, three to five mice in each group were sacrificed for in vivo cytokine analysis. Animal care and handling conformed to the National Institute of Health's Guide for the Care and Use of Laboratory Animals. ${ }^{21}$

\section{Determination of proteinuria and life span}

Proteinuria was measured by using a tetrabromphenol paper (Eiken Chemical Co., Tokyo, Japan) on fresh urine samples. This colorimetric assay, which is relatively specific for albumin, was graded $1+$ to $4+$ and the approximate protein concentrations were as follows: $1+, 0.3 \mathrm{~g} / \mathrm{l} ; 2+, 1 \mathrm{~g} / \mathrm{l} ; 3+, 10 \mathrm{~g} / 1$ and $4+,>10 \mathrm{~g} / 1$. Proteinuria was defined as a reading higher than $2+$ $(1 \mathrm{~g} / \mathrm{l})$ for two consecutive weeks. Mice were followed up for life span and proteinuria every week.

\section{Assay of anti-double-stranded (ds) DNA and anti- cardiolipin antibodies}

Mice were bled retro-orbitally every month to determine serum levels of. Anti-dsDNA and anticardiolipin antibodies in MRL-lpr/lpr mice were assayed by enzyme-linked immunosorbent assay (ELISA), according to a previous study. ${ }^{22}$ The 96well plates were coated with methylated bovine serum albumin (mBSA; Sigma, St Louis, Missouri, USA) or protamine sulphate (Sigma). After overnight incubation, the plates were washed and calf thymus dsDNA or bovine heart cardiolipin was coated overnight at $4{ }^{\circ} \mathrm{C}$. The plates were washed and blocked with gelatin solution for $2 \mathrm{~h}$. After washes, properly diluted serum samples were added in the plates. Two hours later, the plates were washed and horseradish peroxidase-conjugated goat anti-mouse $\gamma$ chainspecific antibodies were added. Enzyme activity was evaluated using ABTS [2, 20-azino-bis (3ethylbenzthazoline-6-sulfonic acid); Sigma] as the substrate. Absorbance was measured at $405 \mathrm{~nm}$ [optimal density (OD)] within $20 \mathrm{~min}$.

\section{Assay of cytokine production from immune cells}

Splenocytes and peritoneal exudate cells (PEC) were harvested from three to five mice at age 15 weeks in each group. Splenocytes at a concentration of $5 \times 10^{6} \mathrm{cells} / \mathrm{ml}$ and PEC at a concentration of $1.5 \times 10^{6}$ cells $/ \mathrm{ml}$ were placed in 48 -well plates in RPMI-1640 medium supplemented with 10\% TCM (mouse serum replacement; Celox Corp., Hopkins, Minnesota, USA). Optimal concentrations selected 
816

from preliminary test of mitogens [phytohaemagglutinin (PHA) $10 \mathrm{mg} / \mathrm{l}$; lipopolysaccharide (LPS) $10 \mathrm{mg} / \mathrm{l}$; Sigma] were added as a stimulus for cell cultures. Suspensions were cultured at $37^{\circ} \mathrm{C}$ in a $5 \% \mathrm{CO}_{2}$ humidified incubator. After 48-h incubation, cell supernatants were collected for measurement of cytokine production. Cytokines including interferon (IFN)- $\gamma$, interleukin (IL)-6 and TNF- $\alpha$ were assayed by using the commercial ELISA kit. Briefly, antiIFN- $\gamma$, IL-6 (PharMingen, SanDiego, California, USA) and TNF- $\alpha$ (R\&D Systems, Minneapolis, Minnesota, USA) antibodies were coated to 96-well ELISA plate and incubated at $4{ }^{\circ} \mathrm{C}$ overnight. After washes, the wells were blocked with $200 \mathrm{ml}$ blocking solution (PBS buffer containing 1\% bovine serum albumin; Sigma) at $25^{\circ} \mathrm{C}$ for $1 \mathrm{~h}$. The plates were washed with PBS containing $0.5 \mathrm{ml}$ Tween 20/1, the supernatant then being added and the plates incubated at $25^{\circ} \mathrm{C}$ for $2 \mathrm{~h}$. The plates were then washed before adding biotin-conjugated anti-IFN- $\gamma$, -IL-6 (PharMingen) and -TNF- $\alpha$ antibodies (R\&D Systems) at $25^{\circ} \mathrm{C}$ for $2 \mathrm{~h}$. After washing, horseradish peroxidase-conjugated streptavidin was added at $25^{\circ} \mathrm{C}$ for $30 \mathrm{~min}$. After washing, the plates were incubated with ABTS or TMB (tetramethylbenzidine; Clinical Science Products, Mansfield, Massachusetts, USA) and measured for absorbance at $415 \mathrm{~nm}$ or $620 \mathrm{~nm}$ within $20 \mathrm{~min}$. The data were calculated according to the cytokine standard curve.

\section{Assay of oestrogenic activity}

Soy isoflavone had to be extracted in organic solvent and its extract can be used for the measurement of oestrogenic activity. Briefly, Phyto Soya ${ }^{\mathrm{TM}}$ isoflavones were properly weighed and extracted in $80 \%$ methanol $(1: 30, \mathrm{w} / \mathrm{v})$ by stirring at room temperature for 1 day. The methanol solution was filtered, and the filtrate was evaporated in a rotary evaporator to remove the solvent. The methanol extract of soy isoflavones was dissolved in 50\% ethanol solution for cell treatment. Oestrogenic activity was measured by the ER transactivation assay as described previously 23 and the procedure of transactivation was based on the report of Chao and Huang. ${ }^{24}$

In short, $1.25 \times 10^{5}$ cells $/ \mathrm{ml}$ CHO-K 1 cells $(\mathrm{CCRC}$ 60006) were seeded at 96-well plate and transfected with $0.3 \mu \mathrm{g}$ of the chimeric receptor construct $\mathrm{pBK}$ CMVGal4-hER $\alpha$ (or $\beta$ ) and pBK-CMV-(UAS) -tk- $^{-}$ alkaline phosphatase (AP) $(4: 1$ or $5: 1)$ in $100 \mu \mathrm{l}$ serum-free medium OPTI-MEM (Gibco BRL, Gaithersburg, Maryland, USA) containing $1 \mu 1$ lipofectamine per well. After $5 \mathrm{~h}$, the medium was changed to Ham's F-12 medium containing 10\% TCM and vehicle (ethanol), $1 \mathrm{nM}$ 17 $\beta$-estradiol (E2, as the positive control) or the appropriate concentration of soy isoflavones. After 48-h incubation, $20 \mu \mathrm{l}$ $(\mathrm{ER} \alpha)$ and $10 \mu \mathrm{l}(\mathrm{ER} \beta)$ culture medium was transferred to a new 96-well plate and mixed with $200 \mu \mathrm{l}$ of SEAP (secreted alkaline phosphatase) assay solution. Finally, the absorbance was read at $405 \mathrm{~nm}$ in 15 min. Fold activation was calculated by taking the AP activity of vehicle-treated cells as 1 . Experiments were repeated in triplicate.

\section{Statistical analysis}

Data were presented as mean \pm standard error (SE) for each group. The significance of differences among groups was analysed by one-way ANOVA (Analysis of Variation) and Duncan's Multiple Range test or Student $t$-test using the SAS software program (SAS/STAT version 8; SAS Institute, Cary, North Carolina, USA). The data of the proteinuria cumulative occurrence and survival were analysed between two different curves using the Cox proportional hazards regression test (STATA version 6.0; Stata Corp., College Station, Texas, USA). Statistical significance was considered at a $P$-value $\leq 0.05$.

\section{Results}

\section{Changes of mice body weight}

MRL-lpr/lpr mice were fed AIN-76 diet and supplemented with various doses of Phyto Soya ${ }^{\mathrm{TM}}$ isoflavones or TAM by tube-feeding beginning at 8 weeks of age. The growth curve (Figure 1) showed that mice in all groups gradually increased body weights that are almost comparable to 14 weeks of age. After age 14 weeks, the body weights of mice in the control group decreased, while others did not. The mice of the Isf 2, Isf 10 and Isf 20 groups started to lose weight at age 16,19 and 23 weeks respectively. Average body weight of the Isf 20 group was significantly higher than that of the control group since age 16 weeks. This data show that Isf supplement attenuates autoimmune-prone weight loss in MRL-lpr/lpr mice.

\section{Effects of isoflavones on mice survival}

The survival rate of mice in the control group decreased with age, and was $46 \%$ at age 18 weeks (Figure 2). At the same age, mice in the Isf 20 group had a $92 \%$ survival, comparable to the TAM group. The survival rate of the Isf group was higher than that of the control group $(P=0.001$, Cox's proportion hazards regression test). Subsequently, the average life span of the Isf 20 group (186 \pm 51 days) and the TAM group (167 \pm 43 days) were significantly longer than the control group (131 \pm 28 days, $P=0.002$ and $P=0.019$, respectively, Student's $t$-test). The life span of the mice in the Isf 2 (154 \pm 41 days) and the Isf 10 


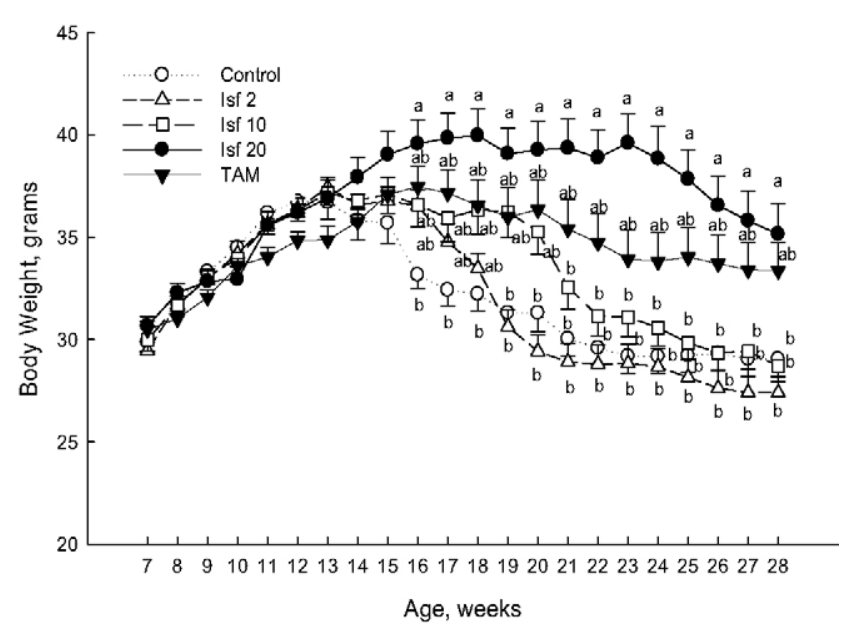

Figure 1 The body weight of MRL-lpr/lpr mice supplemented with sunflower oil (Control, ...凶...) or different doses of soy isoflavone $(2 \mathrm{mg} / \mathrm{kg} \mathrm{BW},-\square-; 10 \mathrm{mg} / \mathrm{kg} \mathrm{BW},-\square-; 20 \mathrm{mg} / \mathrm{kg}$ BW, - - ) or tamoxifen (TAM, $0.375 \mathrm{mg} / \mathrm{kg} \mathrm{BW},-\nabla-$ ) at different ages. There were 12 mice at the age, 8 weeks, started on each supplement diet. Body weights of mice were recorded every week and the values were expressed as mean \pm SE values. Values not sharing the same letter among groups are considered significant differences by Duncan's multiple range test $(P<0.05)$

(155 \pm 48 days) groups were not significantly different from that of the control group.

\section{Influence on autoantibody production}

Because MRL-lpr/lpr mice had hyper-gammaglobulinaemia, the serum levels of autoantibodies were followed up regularly every month. Serum levels of anti-dsDNA IgG and anti-cardiolipin IgG increased with age (Figure 3). At age 14 weeks, the TAM group, as a positive treatment group, had significantly lower serum anti-dsDNA $\mathrm{IgG}$ and anticardiolipin IgG levels. The Isf supplement groups had lower anti-dsDNA and anti-cardiolipin IgG levels, especially significantly for anti-cardiolipin IgG levels in mice of the Isf 10 and Isf 20 groups (Figure $3 \mathrm{~B}$ ). At age 18 weeks, serum anti-cardiolipin IgG elevated and remained the same profile but did not show statistical difference. Serum anti-dsDNA IgG level was not significantly different among the groups because those levels of the Isf supplement and TAM groups elevated.

\section{Effects of isoflavones on cytokines production}

To investigate whether soy isoflavones affect cellular function, Isf-supplemented mice at age 15 weeks were killed and the spleen cells were harvested to culture for cytokine measurement. The data showed that PHAstimulated IFN- $\gamma$ secretion from splenocytes was significantly reduced in the Isf 20 and TAM groups (Figure 4). No significant differences in IL-6 and TNF- $\alpha$

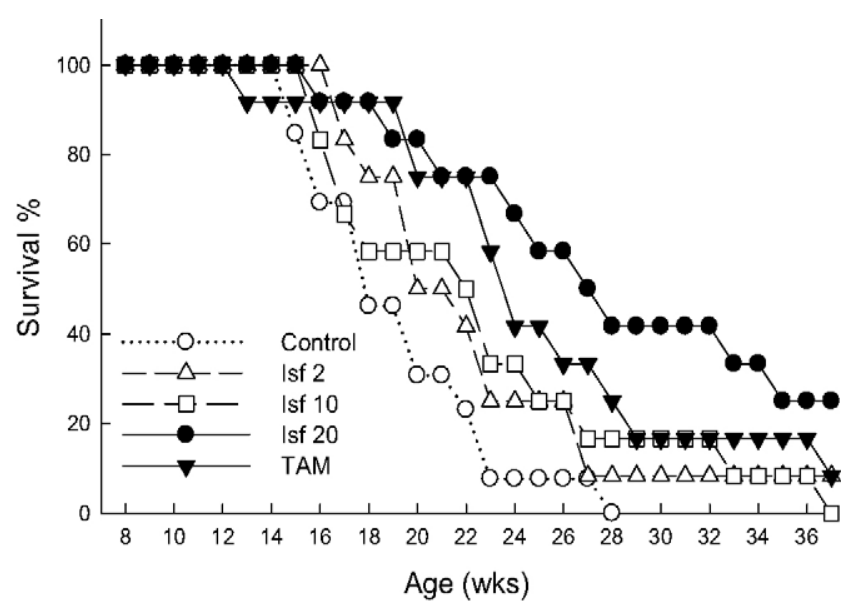

Figure 2 The survival curve of MRL-lpr/lpr mice supplemented with sunflower oil (Control, ...凶...) or different doses of soy isoflavone $(2 \mathrm{mg} / \mathrm{kg} \mathrm{BW},-\square-; 10 \mathrm{mg} / \mathrm{kg} \mathrm{BW},-\square-; 20 \mathrm{mg} / \mathrm{kg}$ BW, - - ) or tamoxifen (TAM, $0.375 \mathrm{mg} / \mathrm{kg} \mathrm{BW},-\boldsymbol{\nabla}-$ ). There were 12 mice at the age, 8 weeks, started on each supplement diet. Survival data were analysed by Cox's proportion hazards regression test. The survival percentage of Isf 20 was higher than that of the control group, $P=0.001$

production from LPS-stimulated PEC were noted between the Isf-supplemented or TAM-treated groups and the control group.

\section{Effects of isoflavones on proteinuria}

MRL-lpr/lpr mice have a rapid onset of glomerulonephritis with proteinuria. Table 1 showed that proteinuria developed early in the control group. Mice treated with TAM, which has been shown to alleviate disease severity, ${ }^{12}$ had delayed onset of proteinuria. Almost half of mice developed proteinuria by age 16 weeks except those treated with TAM. There was no significant difference in proteinuria occurrence after the age of 16 weeks between the Isfsupplemented groups (Isf 2, 10 and 20) and the control group.

\section{Oestrogenic activity of Phyto Soya ${ }^{T M}$ isoflavones}

To determine the oestrogen activity of Isf supplement, Phyto Soya ${ }^{\mathrm{TM}}$ isoflavones were extracted in $80 \%$ methanol and added to two transfected CHO-K1 cells lines with constructs of either ER $\alpha$ or ER $\beta$ ligand-binding domain respectively. It was shown that Isf methanol extract exhibited a higher oestrogenic activity towards ER $\beta$ and a lower ER $\alpha$ oestrogenic activity (Figure 5). The transactivation of Isf methanol extract on ER $\beta$ reached levels as high as $1 \mathrm{nM}$ E2 treatment at a concentration of $10 \mu \mathrm{g} / \mathrm{ml}$, while the activation of ER $\alpha$ was still below half of that of E2 treatment even at a concentration of $80 \mu \mathrm{g} / \mathrm{ml}$ Isf extract. 

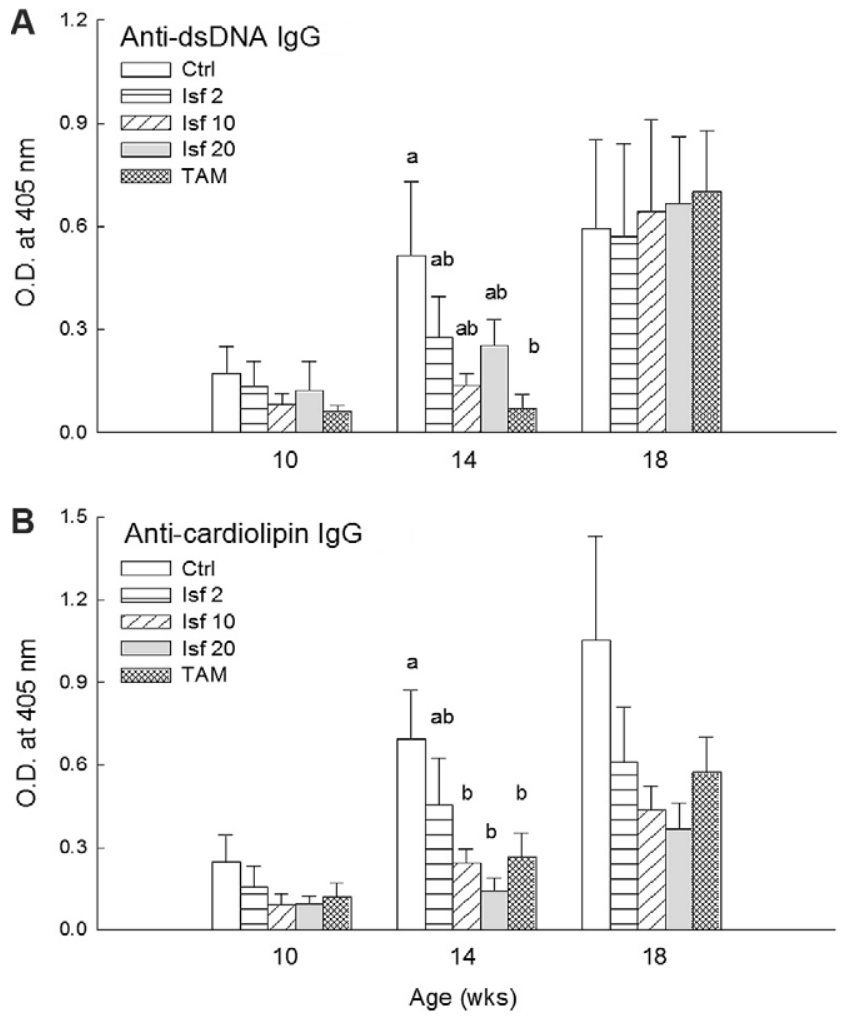

Figure 3 Effects of soy isoflavones supplement on serum levels of anti-dsDNA $\operatorname{IgG}(\mathrm{A})$ and anti-cardiolipin $\operatorname{IgG}(\mathrm{B})$ in MRLlpr/lpr mice. Soy isoflavone supplement started at age 8 weeks (12 mice/group at age $8-10$ weeks; 11 mice/TAM at age 14 weeks; 6-9 mice/group at age 18 weeks). Bar values (optimal density at $405 \mathrm{~nm}$ ) were mean $\pm \mathrm{SE}$ values. Values not sharing the same letter among groups are considered significant differences by Duncan's multiple range test $(P<0.05)$

\section{Discussion}

MRL-lpr/lpr mice develop SLE-like autoimmune syndromes by $3-4$ months of age with progressive tissue damage and weight loss eventually. ${ }^{25}$ In this study, mice of the Isf 20 and TAM groups older than age 14 weeks still maintained their body weights and had longer life span. These data showed that soy isoflavones supplement could benefit survival in murine lupus model.

The production of autoantibodies, particularly anti-dsDNA antibody, and the severity of glomerulonephritis in MRL-lpr/lpr mice was correlated. ${ }^{26-28}$ Another autoantibody, anti-cardiolipin antibody, present in the serum of lupus patients is associated with arterial thrombosis and atherosclerosis. ${ }^{29-31} \mathrm{In}$ MRL-lpr/lpr mice, serum levels of anti-cardiolipin antibody were initially detected at 8 weeks and continued to elevate by age, then peaked around 20 weeks. ${ }^{32}$ Previous studies showed that TAM treatment reduced B-cell count, modulated expression of cytokine receptors, decreased double negative $\mathrm{T}$ cells, and subse-

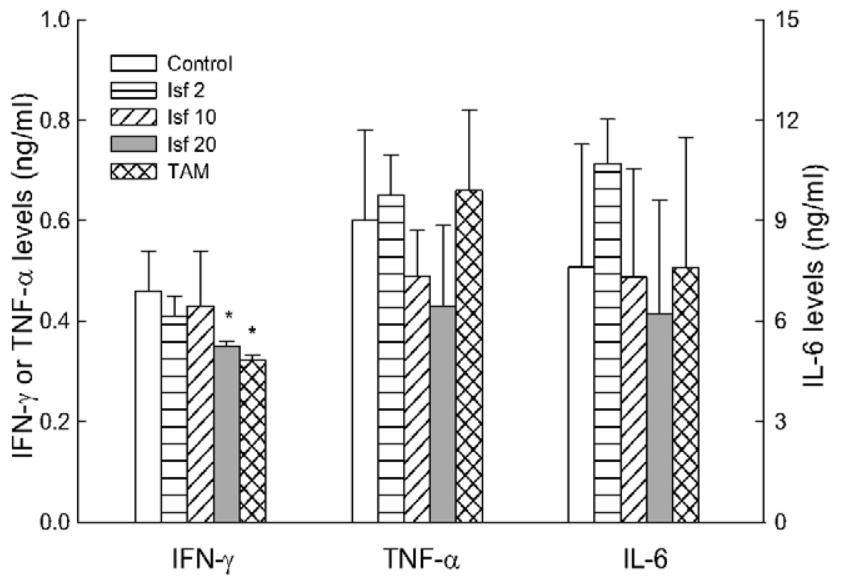

Figure 4 Effects of soy isoflavones supplement on the cytokine secretion from mitogen-stimulated primary cells of MRL-lpr/lpr mice. At age 15 weeks, three to five mice in each group were killed and primary cells were collected. Splenocytes were stimulated with $10 \mathrm{mg} / \mathrm{l}$ PHA for IFN- $\gamma$ assay and peritoneal exudate cells were stimulated with $10 \mathrm{mg} / 1$ LPS for TNF- $\alpha$ and IL-6 assay. Bar values were mean \pm SE values and significantly different from the control group as determined by Student's $t$ test, $* P<0.05$

quently delayed disease onset and alleviated symptoms of lupus nephritis in MRL-lpr/lpr mice. ${ }^{12}$ In this study, serum levels of anti-dsDNA and anticardiolipin $\mathrm{IgG}$ were significantly reduced in the TAM group until age 18 weeks. The Isf 10 and Isf 20 groups also had lower serum anti-cardiolipin $\mathrm{IgG}$ and anti-dsDNA IgG, especially significant for anticardiolipin $\mathrm{IgG}$ at age 14 weeks. Although serum levels of anti-dsDNA IgG of isoflavones supplement and TAM groups elevated at age 18 weeks, there was no significant difference among the groups. Serum anti-cardiolipin IgG profile remained the same at 18 weeks but did not show statistical difference. This profile is similar to those studies regarding the dietary

Table 1 The cumulative occurrence of proteinuria of MRLlpr/lpr mice at different ages ${ }^{\mathrm{a}}$

\begin{tabular}{lrrll}
\hline \multirow{5}{*}{ Group } & \multicolumn{4}{l}{ Age, weeks } \\
\cline { 2 - 5 } & 10 & \multicolumn{1}{l}{12} & 16 & \multicolumn{1}{l}{20} \\
\hline Control & $17(2)$ & $25(3)$ & $42(5)$ & $58(7)$ \\
Isf2 & $8(1)$ & $8(1)$ & $42(5)$ & $67(8)$ \\
Isf10 & $8(1)$ & $17(2)$ & $58(7)$ & $75(9)$ \\
Isf20 & $8(1)$ & $17(2)$ & $42(5)$ & $50(6)$ \\
TAM & $0(0)^{*}$ & $0(0)^{*}$ & $17(2)^{*}$ & $42(5)$ \\
\hline
\end{tabular}

The significant difference between the control group and the experimental group was analysed by COX's proportion hazards regression test, * $P<0.05$.

a Data were expressed as the percentage of cumulative proteinuria occurrence and the number of mice with proteinuria in parenthesis. Mice with proteinuria were defined as those with more than $1 \mathrm{~g} / \mathrm{l}$ protein for two consecutive weeks using tetrabromphenol papers. 


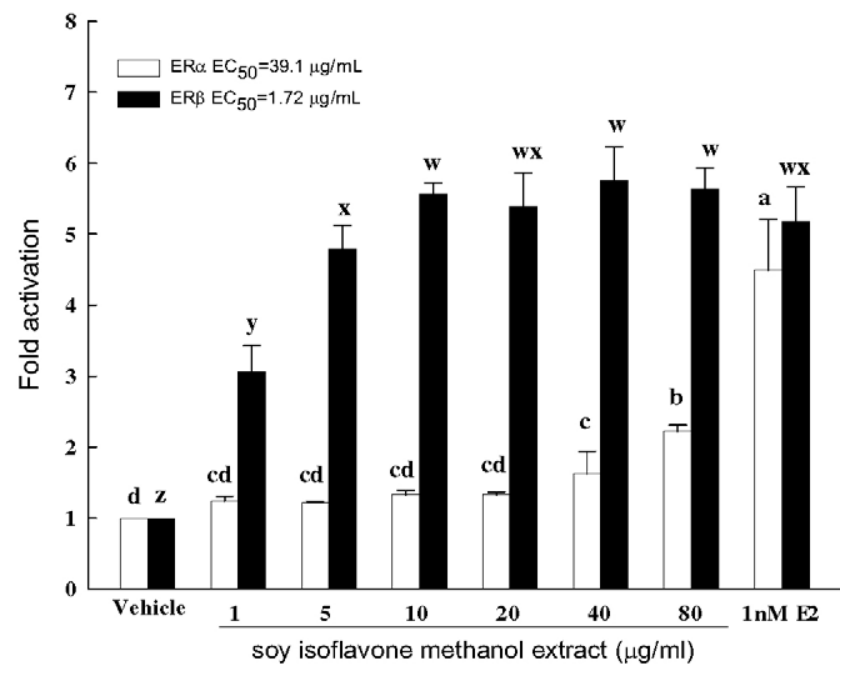

Figure 5 Effects of soy isoflavones methanol extract on the transcriptional activation of oestrogen receptors (Gal4-hER $\alpha$ or $\beta)$. Values are expressed as mean $\pm \mathrm{SE}$ values of three separate experiments, and $1 \mathrm{nM}$ E2 (17 $\beta$-estradiol) as the positive control. Vehicle represents the treatment of $0.1 \%$ ethanol to cells. Values not sharing the same letter are significantly different by Duncan's multiple range test $(P<0.05, \mathrm{~A}-\mathrm{D}$ represents the significant difference for $\mathrm{ER} \alpha$ activities, while $\mathrm{W}-\mathrm{Z}$ represents for $\mathrm{ER} \beta$ )

effects on serum autoantibodies levels. It has been shown that significant differences of serum autoantibodies levels were usually observed at age 3-4 months in MRL-lpr/lpr and 6-7 months in NZB/W F1 mice, 33-35 except those on extreme nutrient deficient or calorie restriction diets. ${ }^{36,37}$ Significantly higher serum autoantibody levels among groups were not necessarily observed at later stage of disease course, possibly due to individual variation and antibody deposit in kidney. These data suggested that the inhibitory effect of soy isoflavones on the production of autoantibodies, especially at the age when disease course starts, might contribute to delay the disease course.

The dysregulation of pro- vs. anti-inflammatory mediators is the characteristic of autoimmune disease. Pro-inflammatory cytokines such as IFN- $\gamma$, TNF- $\alpha$ and IL-6 appear to be upregulated in lupus kidney. ${ }^{38}$ IFN- $\gamma$ enhanced the production of inflammatory mediators which worse glomerulonephritis. The treatment of IFN- $\gamma$-encoding plasmid reduced the survival, while the deletion of the IFN- $\gamma$ receptor or disrupted IFN- $\gamma$ gene prevented autoantibody production and had a longer life span in SLE-like mice. ${ }^{39-41}$ TNF- $\alpha$ and IL-6 levels are elevated in both human and murine lupus and also play the critical roles in the pathogenesis of autoimmune. ${ }^{42}$ It was addressed that agents to neutralize cytokines, such as IFN- $\gamma, \mathrm{TNF}-\alpha$, IL-6 and IL-18, could ameliorate disease severity in lupus-like mice. ${ }^{38}$
Nevertheless, the cytokine production can be modulated by diet treatment. In vitro studies have shown that isoflavones exert anti-inflammatory properties via various mechanisms, such as antioxidant effects, inhibition of signal transduction or PPAR $\gamma .{ }^{43-45}$ Lower production of IL-1 $\beta$, IL-6, nitric oxide (NO) and prostaglandin $\mathrm{E}_{2}\left(\mathrm{PGE}_{2}\right)$ by PEC from LPSinduced inflammatory mice fed isoflavones was reported recently. ${ }^{18}$ However, information about the inhibitory effects of dietary isoflavones on ex vivo production of pro-inflammatory cytokines in lupus mice is limited. Data presented here show that IFN- $\gamma$ is the cytokine that were significantly reduced in the Isf 20 and TAM groups compared with the control. Lower IFN- $\gamma$ secretion was consistent with lower serum antidsDNA IgG levels at age 14 weeks and longer life span in soy isoflavones supplement group. This result is in accordance with the previous report that significantly lower IFN- $\gamma$ secretion and longer life span were found in vitamin E-supplemented NZB/W F1 mice fed oxidized oil diet, ${ }^{33}$ suggesting that IFN- $\gamma$ is a potential target for anti-inflammatory diet therapy. TNF- $\alpha$ and IL- 6 productions from LPS-stimulated PEC of mice at age 15 weeks were not significantly reduced by soy isoflavones and tamoxifen treatment in this study, which was also observed in the previous study on tamoxifen treatment in murine lupus. ${ }^{11}$ Our study showed that decreased IFN- $\gamma$ level produced by splenocytes in treatment groups, which is important for the aggravation of inflammation in late stage of murine lupus. The results suggest that soy isoflavones decrease not only anti-dsDNA antibody levels in early stage but also inflammation in late stage of murine lupus. These findings might explain why the soy isoflavones treatment groups had the better survival rate compared with that of the control group.

In addition, oestrogen endocrine disruptors, such as genistein, can also decrease IFN- $\gamma$ production. ${ }^{46}$ Oestrogen alters cytokine gene regulation in lupus $\mathrm{T}$ cells, involved in disease progression and mediate through the ER pathway. ${ }^{47,48}$ IFN- $\gamma$ production was also reduced in NZB/W F1 mice fed bisphenol A, a synthetic oestrogen receptor-binding molecule. ${ }^{49}$ Bisphenol $A$ binds ER $\beta$ with sixfold greater affinity than $\mathrm{ER} \alpha,{ }^{50}$ and increased symptom-free period of NZB/ W F1 mice. ${ }^{49}$ Interestingly, we also found that the soy isoflavones supplement used in this study showed a higher affinity for ER $\beta$ than ER $\alpha$ by transactivation assay. Our results are consistent with the recent study that the disease severity is aggravated by an ER $\alpha$ agonist, but ameliorated by a preferred ER $\beta$ agonist in murine lupus model, suggesting that ligand with higher binding affinity to ER $\beta$ and $\mathrm{ER} \alpha$ may contribute to immunosuppressive effect on this disease. ${ }^{35}$ 
Although the reason for this disparity is unclear, the role of ER $\alpha$ expression by $\mathrm{T}$ cells in oestrogen-induced IL-4 production and in suppressing IFN- $\gamma$ production, which cause cytokine imbalance for disease onset, may be one of the possible explanations. ${ }^{51,52}$ The action of ER $\beta$ can be opposite to ER $\alpha$, and ER $\beta$ ligands have been developed for medical treatment of different hormone-dependent diseases. ${ }^{53}$ Further studies investigating its mechanism are warranted.

However, a report showed that a $20 \%$ soy protein diet, when compared with a casein diet, exacerbate renal damage in MRL-lpr/lpr mice. ${ }^{54}$ As higher Con A-stimulated proliferation in soy diet is the only immune response shown to be significantly different in that study, it is difficult to evaluate precisely the different effects of the $20 \%$ soy protein and the soy isoflavone used in our present study at this point. It might be due to different plasma concentrations of various isoflavones depending on feeding soy products, ${ }^{55}$ or the timing of feeding began. However, the effects of soy protein on renal damage in autoimmune-prone mice still need to be clarified. Our observation in this study showed that an adequate supplementation of soy isoflavones would benefit lupus-like conditions in autoimmune diseases.

In summary, this study showed that soy isoflavone decreased serum anti-dsDNA IgG and anticardiolipin IgG levels at the age when disease course develops, decreased IFN- $\gamma$ secretion from PHAstimulated $\mathrm{T}$ cells and prolonged life span. A higher affinity towards ER $\beta$ than ER $\alpha$ of this soy isoflavone product might be also one of the contributing factors. Therefore, dietary supplementation of soy isoflavones did not aggravate disease but apparently alleviate disease severity in murine lupus model.

\section{Acknowledgements}

The authors disclose that there is no conflict of interest in this study. We are grateful to Ching-Jang Huang and Wei-Yi Cheng for the analysis of oestrogenic activities. This work was kindly supported by a grant from the National Science Council of the Republic of China (NSC 93-2321-B-002-014).

\section{References}

1 Lahita, RG. The importance of estrogen in systemic lupus erythematosus. Clin Immunol Immunopathol 1992; 63: 17-18.

2 Cooper, GS, Dooley, MA, Treadwell, EL, St. Clair, EW, Parks, CG. Hormonal, environmental, and infectious, risk factors for developing systemic lupus erythematosus. Arthritis Rheum 1998; 41: 1714-1724.

3 Whitacre, CC, Reingold, SC, O'Looney, PA. A gender gap in autoimmunity. Science 1999; 283: 1277-1278.

4 Garovich, M, Agudelo, C, Pisko, E. Oral contraceptives and systemic lupus erythematosus. Arthritis Rheum 1980; 23: 1396-1398.

5 Holmdahl, R. Estrogen exaggerates lupus but suppresses Tcell-dependent autoimmune disease. J Autoimmun 1989; 2: 651-656.
6 Carlsten, H, Tarkowski, A, Holmdahl, R, Nilsson, LA. Oestrogen is a potent disease accelerator in SLE-prone MRL-lpr/lpr mice. Clin Exp Immunol 1990; 80: 467-473.

7 Auborn, KJ, Qi, M, Yan, XJ, et al. Life span is prolonged in autoimmune-prone (NZB/NZW) F1 mice fed a diet supplemented with indole-3-carbinol. $J$ Nutr 2003; 133: 3610-3613.

8 Jordan, VC. Fourteenth Gaddum Memorial Lecture. A current view of tamoxifen for the treatment and prevention of breast cancer. $\mathrm{Br} J$ Pharmacol 1993; 110: 507-517.

9 Nayfield, SG. Tamoxifen's role in chemoprevention of breast cancer: an update. J Cell Biochem 1995; 22(Suppl.): 42-50.

10 Dayan, M, Zinger, H, Kalush, F, et al. The beneficial effects of treatment with tamoxifen and anti-oestradiol antibody on experimental systemic lupus erythematosus are associated with cytokine modulations. Immunology 1997; 90: 101-108.

$11 \mathrm{Wu}, \mathrm{WM}$, Lin, BF, Suen, JL, Chiang, BL. Tamoxifen decreases renal inflammation and alleviates disease severity in autoimmune NZB/W F1 mice. Scand J Immunol 2000; 52: 393-400.

$12 \mathrm{Wu}, \mathrm{WM}$, Suen, JL, Lin, BF, Chiang, BL. Tamoxifen alleviates disease severity and decreases double negative $\mathrm{T}$ cells in autoimmune MRL-lpr/lpr mice. Immunology 2000; 100: 110-118.

13 Andrews, BS, Eisenberg, RA, Theofilopoulos, AN, et al. Spontaneous murine lupus-like syndromes. Clinical and immunopathological manifestations in several strains. J Exp Med 1978; 148: 1198-1215.

14 Cohen, PL, Eisenberg, RA. Lpr and gld: single gene models of systemic autoimmunity and lymphoproliferative disease. Annu Rev Immunol 1991; 9: 243-269.

15 Pollard, KM, Pearson, DL, Hultman, P, Hildebrandt, B, Kono, DH Lupus-prone mice as models to study xenobiotic-induce acceleration of systemic autoimmunity. Environ Health Perspect 1999; 107(Suppl. 5): $729 \mathrm{~S}-735 \mathrm{~S}$.

16 Birt, DF, Hendrich, S, Wang, W. Dietary agents in cancer prevention: 9 flavonoids and isoflavonoids. Pharmacol Ther 2001; 90: 157-177.

17 Tsai, M, Clark, JM, Schrader, WT, O'Malley, BW. Mechanism of action of hormones that act as transcription-regulatory factors. In: Wilson, JD, Foster, DW, Kronenberg, HM, Larsen, PR, (eds), Williams textbook of endocrinology. Philadelphia, PA: WB Saunders Co.; 1998. p. 55-94.

18 Kao, TH, Wu, WM, Hung, CF, Wu, WB, Chen, BH. Antiinflammatory effects of isoflavone powder produced from soybean cake. J Agric Food Chem 2007; 55: 11068-11079.

19 Velasquez, MT, Bhathena, SJ. Dietary phytoestrogens: a possible role in renal disease protection. Am J Kidney Dis 2001; 37: 1056-1068.

20 American Institute of Nutrition. Report of the American Institute of Nutrition Ad Hoc Committee on Standards for Nutritional Studies. $J$ Nutr 1997; 107: 1340-1348.

21 National Research Council. Guide for the care and use of laboratory animals. Bethesda, MD: National Institutes of Health; 1985. Publication No. 85-23.

22 Lin, BF, Jeng, SJ. Effects of dietary frying oil on lipids and anticardiolipin antibody levels in autoimmune-prone NZB/W F1 mice. Nutr Res 1997; 17: 1047.

23 Kuo, LC, Cheng, WY, Wu, RY, Huang, CJ, Lee, KT. Hydrolysis of black soybean isoflavone glycosides by Bacillus subtilis natto. Appl Microbiol Biotechnol 2006; 73: 314-320.

24 Chao, CY, Huang, CJ. Bitter gourd (Momordica charantia) extract activates PPAR and up-regulates the expression of acyl CoA oxidase gene in H4IIEC3 hepatoma cells. J Biomed Sci 2003; 10: 782-791.

$25 \mathrm{Hahn}, \mathrm{BH}$. Animal models of systemic lupus erythematosus. In: Wallace, DJ, Hahn, BH, (eds), Dubois' lupus erythematosus. Baltimore: Williams, and Wilkins; 1997. p. 339-356.

26 Jonsson, R, Tarkowski, A, Backman, K, Holmdahl, R, Klareskog, L. Sialadenitis in the MRL-1 mouse: morphological and immunohistochemical characterization of resident and infiltrating cells. Immunology 1987; 60: 611-616.

27 Tarkowski, A, Jonsson, R, Sanchez, R, Klareskog, L, Koopman, WJ. Features of renal vasulitis in autoimmune MRL-lpr/lpr mice: phenotypes and functional properties of infiltrating cells. Clin Exp Immunol 1988; 72: 91-97.

28 Loizou, S, Samarko, M, Norsworthy, PJ, Cazabon, JK, Walport, MJ, Davies, KA. Significance of anticardiolipin and anti-beta 2glycoprotein I antibodies in lupus nephritis. Rheumatology 2000; 39: 962-968. 
29 Gharavi, AE, Mellors, RC, Elkon, KB. IgG anti-cardiolipin antibodies in murine lupus. Clin Exp Immunol 1989; 78: 233-238.

$30 \mathrm{McNeil}$, HP, Chesterman, CN, Krilis, SA. Immunology and clinical importance of antiphospholipid antibodies. Adv Immunol 1991; 49 193-280.

31 Ahmed, AS, Boone, J. Anticardiolipin antibodies in autoimmuneprone $\mathrm{BXSB}$ and $\mathrm{MRL} / \mathrm{lpr}$ mice, and estrogen-treated normal C57BL/6J mice cross-react with other phospholipids. Int J Immunopathol Pharmacol 1993; 6: 135-147.

32 Hashimoto, Y, Kawamura, M, Ichikawa, K, et al. Anticardiolipin antibodies in NZW $\times$ BXSB F1 mice. J Immunol 1992; 149: 10631068 .

33 Hsieh, CC, Lin, BF. The effects of vitamin E supplementation on autoimmune-prone NZB/W F1 mice fed an oxidized oil diet. $\mathrm{Br} J$ Nutr 2005; 93: 655-622.

34 Hsieh, CC, Lin, BF. Opposite effects of low and high dose supplementation of vitamin E on survival of MRL-lpr/lpr mice. Nutrition 2005; 21: $940-948$

$35 \mathrm{Li}, \mathrm{J}$, McMurray, RW. Effects of estrogen receptor subtype-selective agonists on autoimmune disease in lupus-prone NZB/NZW F1 mouse model. Clin Immunol 2007; 123: 219-226.

36 Kubo, C, Johnson, BC, Day, NK, Good, RA. Calorie source, calorie restriction, immunity and aging of NZB/W F1 mice. $J$ Nutr 1984; 114: 1884-1899.

37 Urao, M, Ueda, G, Abe, M, Kanno, K, Hirose, S, Shirai, T. Food restriction inhibits an autoimmune disease resembling systemic lupus erythematosus in (NZBxNZW) F1 mice. J Nutr 1995; 125: 23162324 .

38 Aringer, M, Smolen, JS. Cytokine expression in lupus kidneys. Lupus 2005; 14: 13-18.

39 Balomenos, D, Rumold, R, Theofilopoulos, AN. IFN- $\gamma$ is required for lupus-like disease and lymphoaccumulation in MRL/lpr mice. $J$ Clin Invest 1998; 101: 364-371.

40 Haas, C, Ryffel, B, Hir, ML. IFN- $\gamma$ receptor deletion prevents autoantibody production and glomerulonephritis in lupus-prone (NZB $\times N Z W) ~ F 1$ mice. J Immunol 1998; 160: 3713-3718.

41 Hasegawa, K, Hayashi, T, Maeda, K. Promotion of lupus in NZB $\times$ NZW F1 mice by plasmids encoding interferon (IFN)- $\gamma$ but not by those encoding interleukin (IL)-4. J Comp Pathol 2002; 127: $1-6$.

42 Asanuma, Y, Chung, CP, Oeser, A, et al. Increased concentration of proatherogenic inflammatory cytokines in systemic lupus erythematosus: relationship to cardiovascular risk factors. J Rheumatol 2006; 33 539-545.

43 Verdrengh, M, Jonsson, IM, Holmdahl, R, Tarkowski, A. Genistein as an anti- inflammatory agent. Inflamm Res 2003; 52: 341-346.
44 Hämäläinen, M, Nieminen, R, Vuorela, P, Heinonen, M, Moilanen, E. Anti-inflammatory effects of flavonoids: genistein, kaempferol, quercetin, and daidzein inhibit STAT-1 and NF-kappaB activations, whereas flavone, isorhamnetin, naringenin, and pelargonidin inhibit only NF-kappaB activation along with their inhibitory effect on iNOS expression and NO production in activated macrophages. Mediators Inflamm 2007; 2007: 45673 .

45 Chacko, BK, Chandler, RT, D'Alessandro, TL, et al. Antiinflammatory effects of isoflavones are dependent on flow and human endothelial cell PPARgamma. J Nutr 2007; 137: 351-356.

46 Calemine, J, Zalenka, J, Karpuzoglu-Sahin, E, Ward, DL, Lengi, A, Ahmed, SA. The immune system of geriatric mice is modulated by estrogenic endocrine disruptors (diethylstilbestrol, alpha-zearalanol, and genistein): effects on interferon-gamma. Toxicology 2003; 194: $115-128$.

47 Rider, V, Foster, RT, Evans, MJ, Suenaga, R, Abdou, NI. Gender differences in autoimmune diseases: estrogen increases calcineurin expression in systemic lupus erythematosus. Clin Immunol Immunopathol 1998; 89: 171-180.

48 Rider, V, Jones, SR, Evans, MJ, Abdou, NI. Molecular mechanism involved in the estrogen-dependent regulation of calcineurin in systemic lupus erythematosus T cells. Clin Immunol 2000; 85: 124-134.

49 Sawai, C, Anderson, K, Walser-Kuntz, D. Effect of bisphenol A on murine function: modulation of interferon-gamma, IgG2a, and disease symptoms in NZB $\times$ NZW F1 mice. Environ Health Perspect 2003; 111: 1883-1887.

50 Kuiper, GG, Lemmen, JG, Carlsson, B, et al. Interaction of estrogenic chemicals and phytoestrogens with estrogen receptor beta. Endocrinology 1998; 139: 4252-4263.

51 Curran, EM, Judy, BM, Newton, LG, et al. Dietary soy phytoestrogens and ERalpha signalling modulate interferon gamma production in response to bacterial infection. Clin Exp Immunol 2004; 135: 219 225

52 Lambert, KC, Curran, EM, Judy, BM, Milligan, GN, Lubahn, DB, Estes, DM. Estrogen receptor alpha (ERalpha) deficiency in macrophages results in increased stimulation of CD4+ T cells while 17betaestradiol acts through ERalpha to increase IL-4 and GATA-3 expression in CD4+ T cells independent of antigen presentation. $J$ Immunol 2005; 175: 5716-5723.

53 Imamov, O, Shim, GJ, Warner, M, Gustafsson, JA. Estrogen receptor beta in health and disease. Biol Reprod 2005; 73: 866-871.

54 Zhao, JH, Sun, SJ, Horiguchi, H, et al. A soy diet accelerates renal damage in autoimmune MRL/Mp-lpr/lpr mice. Int Immunopharmacol 2005; 5: 1601-1610.

55 Setchell, KD, Brown, NM, Desai, P, et al. Bioavailability of pure isoflavones in healthy humans and analysis of commercial soy isoflavone supplements. $J$ Nutr 2001; 131: 1362S-1375S. 